\title{
Inventory and Quantitative Assessment of Geosites and Geodiversity Sites: a Review
}

\author{
José Brilha
}

Received: 19 February 2014 / Accepted: 11 December 2014

(C) The European Association for Conservation of the Geological Heritage 2015

\begin{abstract}
The inventory and quantitative assessment of the most valuable occurrences of geodiversity are essential steps in any geoconservation strategy and in the establishment of priorities in site management. Despite the existence of many site inventories applied to different scales (countries, municipalities, parks, etc.), the criteria used for their selection are often unclear and poorly defined. This paper proposes a new approach to the concepts of geosite and geodiversity site and reviews the procedures used in the development of a systematic site inventory applied to different scales and values. Procedures to achieve a numerical evaluation of the value and degradation risk of sites are reviewed and new criteria are proposed. Finally, guidelines are presented, bearing in mind the preparation of effective geodiversity inventories, to support geoparks' strategies. This paper aims to contribute to a better understanding and use of the above-mentioned concepts, which are essential for the implementation of geoconservation actions worldwide.
\end{abstract}

Keywords Geosite · Geoheritage · Geodiversity site · Geopark $\cdot$ Inventory $\cdot$ Geodiversity

\section{The Concepts of Geosite and Geodiversity Site}

All geoscientists recognise the importance of accessing representative geodiversity elements (minerals, rocks, fossils, soils, landforms, etc.) in order to obtain all the necessary data for

J. Brilha $(\bowtie)$

Institute of Earth Sciences, Pole of the University of Minho, Campus de Gualtar, 4710-057 Braga, Portugal

e-mail: jbrilha@dct.uminho.pt research. In many areas of the geosciences, data are obtained in the field in places with specific geodiversity features. In other domains of geosciences, geodiversity occurrences are sampled and laboratory studies are performed aiming to understand the geological and geomorphological evolution of a certain region of the planet. In both cases, those places must be protected in order to allow their scientific use by present and future geoscientists. The scientific value of geodiversity elements is directly related to their importance in supporting present and future knowledge of how the geosphere works and interacts with other Earth systems, namely the biosphere, the hydrosphere, and the atmosphere.

Places that are key locations for unveiling and understanding the Earth's geological history-usually considered geological heritage - are under increasing risk of total or partial deterioration, mainly due to anthropic activities. The inexistence of a systematic and comprehensive inventory means that geological evidence that has supported decades of studies and research, and the spending of vast amounts of public and private money, may disappear forever because most geological materials are non-renewable when the human timescale is taken into consideration. Hence, actual geoscientists must assume the social responsibility of ensuring the conservation of this natural heritage as of paramount importance for the advancement of geosciences and for the knowledge of planet Earth.

The scientific literature reveals a multitude of concepts and definitions concerning geodiversity, geological heritage, geosites, and geoconservation (for instance, Black and Gonggrijp 1990; Elízaga et al. 1994; Gray 2008, 2013; Pena dos Reis and Henriques 2009; Wimbledon 2011). However, these concepts have often been misused and even today it is common to see them applied in quite unconventional ways, particularly by an increasing number of persons that are beginning to work in this domain. This paper does not have the 
intention to discuss these concepts in detail. However, it is necessary to propose a systematic approach given that geoconservation aims at the identification, protection, and management of valuable elements of geodiversity.

Natural diversity includes biotic elements - biodiversityand abiotic elements - geodiversity (Fig. 1). Geological heritage, or geoheritage, refers to (i) in situ occurrences of geodiversity elements with high scientific value - geosites and (ii) ex situ geodiversity elements that, in spite of being displaced from their natural location of occurrence, maintain a high scientific value (for instance, minerals, fossils, and rocks available for research in museum collections) - geoheritage elements. In addition to scientific value, both in situ and ex situ geoheritage may also have educational, aesthetic, and cultural value, which also justify their necessary use by society (teaching/learning, tourism, leisure, etc.). Geoheritage is a general term that encompasses more specific designations when considering particular types of geodiversity elements with exceptional scientific value. Hence, it is common to refer to geomorphological (landforms), petrological (rocks), mineralogical (minerals), palaeontological (fossils), stratigraphic (sedimentary sequences), structural (folds, faults, and others), hydrogeological (water), or pedological (soils) heritage as sub-types of geoheritage. Considering that geoheritage is only justified by the scientific value, the relevance of geoheritage can only be international or national because there is no 'local science'.

Given the immense geological diversity which occurs on our planet, choosing which elements should be selected and protected is not at all an easy task. Based on the most objective criteria and on the scientific knowledge, the identification of the best geosites to be protected should be done by the geoscientific community. Even considering the subjectivity inherent to science, the scientific data are the less subjective and for this reason, they should be primarily used to select the most relevant sites that are representative of the history of the Earth and its evolution.
It should be highlighted that an inventory is always dynamic and needs to be regularly updated. With the advance of scientific knowledge, a certain geosite may lose its scientific value in the future or a new occurrence might gain the geosite status. However, a particular occurrence might still be considered a geosite even if it no longer has a high scientific relevance if, for instance, it is a significant record for the history of geological knowledge. In the UK, some geosites no longer have a high scientific relevance but even so, they are preserved because they are key locations for the understanding of the history of geology.

Obviously, there are many geodiversity elements that do not have a particular scientific value but which are still important resources for education, tourism, or cultural identity of communities (Fig. 1). As with geoheritage, these geodiversity elements can also be found in situ-geodiversity sites - and ex situ. However, they should not be considered geoheritage because this term should only be used when their scientific value is accurately recognised by the national and/or international scientific community. Examples of geodiversity sites might be folded limestone layers with excellent exposition to allow educational activities or landforms with cultural or religious significance for local communities. Ornamental stones with educational and touristic values in monuments and buildings can be considered an example of ex situ geodiversity elements. Sites with high tourism value can also be known as geomonuments; this term is already used to promote geosites to the general public in some countries. Geodiversity sites may have local, national, and international relevance. The term 'geodiversity site' is already being used in the UK, mainly as a replacement for the previous designation of 'Regionally Important Geological/Geomorphological Sites'-RIGS (Prosser et al. 2010; Browne 2012). Geoconservation strategies (Henriques et al. 2011) should be applied to the characterisation and management of all features of geodiversity that show some type of value (Fig. 1). It should
Fig. 1 Conceptual framework of geodiversity, geoheritage, and geoconservation taking into account the scope of geoconservation. Only a small fraction of geodiversity has a relevant value that justifies the implementation of geoconservation strategies, regardless of whether this fraction is considered geoheritage or sites and elements of geodiversity

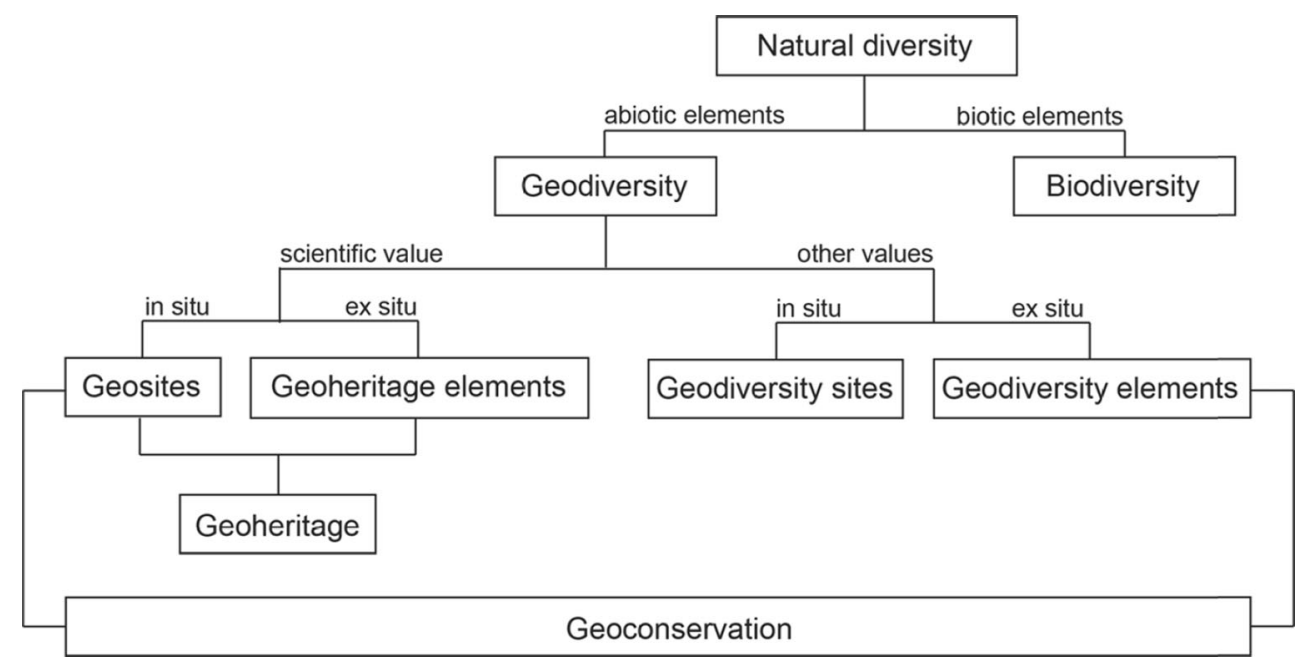


be emphasised that the economic value associated with the exploitation of geological resources is not considered under the scope of geoconservation.

In a certain way, mining heritage is also related to geoheritage and geodiversity. Usually, the term 'mining heritage' applies to whatever is involved in active and inactive mining exploration, such as minerals and rocks that are being (or were) extracted, industrial facilities, historical documentation of old mines, exploitation processes and techniques, and even mining communities' stories and traditions. If mineral and rock occurrences are still available and have scientific value, they should be considered geoheritage (mineralogical or petrological heritage). Sometimes, these occurrences only have educational and/or touristic value and, if this is the case, they should be called geodiversity sites. All the other mentioned assets are considered mining heritage, which is not a specific type of geological heritage. When considering just the industrial and mechanical facilities used during mining activity, the term 'industrial heritage' should be used instead. Experts on industrial archaeology study this type of heritage as a contribution to the history of technology.

The identification and characterisation of sites are decisive steps in any geoconservation strategy (Brilha 2005; Henriques et al. 2011). During the last decades, several countries have been developing national inventories of geosites, namely in Europe (Wimbledon and Smith-Meyer 2012), such as in Poland (Alexandrowicz and Kozlowski 1999), Portugal (Brilha et al. 2005, 2010), Spain (Garcia-Cortés et al. 2001; Carcavilla et al. 2009), Switzerland (Grandgirard 1999), Russia (Lapo et al. 1993), and the UK (Wimbledon et al. 1995). The experience in those and other countries is being used to develop inventory methods that can be adapted to regions with different size areas and diversified geological settings. These methods must take into account a good geological knowledge of the territory, a clear definition of the inventory aims, and the engagement of the earth science community. The development of a national inventory without a solid methodological background may lead to disastrous results because irrelevant sites may be included in the inventory or, even worse, the most relevant geosites of the country may be left out of the inventory. The main aim of this paper is to conduct a review and present a systematic approach to inventory and quantification methods applied to geological heritage and geodiversity sites, under the scope of geoconservation strategies. The procedures for the assessment of geodiversity as a whole, independently of the value of the different elements, is another research domain that has recently been under development by several researchers (for instance, Serrano et al. 2009; Pellitero et al. 2011, 2014; Hjort and Luoto 2012; Pereira et al. 2013; Silva et al. 2014) but it is out of scope of this paper.

\section{Methods for the Inventory of Geological and Geodiversity Sites}

The inventory of geological and geodiversity sites is the first and crucial step in any geoconservation strategy, regardless of the size of the area under analysis. A geoconservation strategy is based on several successive steps: inventory, quantitative assessment, conservation, interpretation and promotion, and, finally, monitoring of sites (Brilha 2005). This paper only discusses the two first stages: inventory and quantitative assessment of sites.

Before initiating an inventory, its aims must be clearly defined by taking four issues into account (Lima et al. 2010): the topic, the value, the scale, and the use. The topic is the subject or theme to be inventoried, for instance, the geological heritage (as a whole), the palaeontological heritage, the geomorphological heritage, a geological framework, etc. The value is closely related to the potential use of the sites and might be scientific, educational, and/or touristic. The scale refers to the size of the area where the inventorying will take place (a natural park, a geopark, a municipality, a state, a country, a continent, etc.). Finally, the use is related to the purpose of the inventoried sites, for instance, to support a national geoconservation strategy, to develop a geotouristic project, to promote the local geodiversity or an educational programme, etc.

The clear definition of the inventory aim is essential for the selection of the correct method to identify sites. The accurate definition of the value of the sites to be inventoried is particularly important in choosing the criteria that should be used for site selection. These criteria are mentioned in almost all literature concerning geoheritage, such as JNCC (1977); Lapo et al. (1993); Wimbledon et al. (1995); Grandgirard (1999); Alexandrowicz and Kozlowski (1999); Parkes and Morris (1999); Gray (2013); Brilha (2005); White and Mitchell (2006); García-Cortés and Carcavilla Urquí (2009); FuertesGutiérrez and Fernández-Martínez (2010); Díaz-Martínez and Díez-Herrero (2011); Wimbledon (2011); Reynard and Coratza (2013). However, many inventory works apply the same criteria regardless of the value of the sites that are being inventoried and this may lead to erroneous results. For instance, the justification of beautiful scenery for the selection of a potential geosite is completely irrelevant because the scientific value is independent of the visual beauty of the site. On the contrary, it is a pertinent criterion to identify a site for tourism use.

If the purpose is to identify sites with scientific value, then it is necessary to develop an inventory of geosites using a set of four criteria (see "Inventory of Geosites"). However, if the aim is to identify sites with educational, touristic and/or cultural values, then an inventory of geodiversity sites is advisable, based on another set of criteria (see "Inventory of Geodiversity Sites"). 
Inventory of Geosites

The present proposal for obtaining a systematic and solid inventory of geosites is based on several positive aspects published in different scientific studies (references above) and on the author's own experience. As explained before, it should be emphasised that, concerning geosites, only the scientific value (SV) is considered for the inventory. Taking into account the size of the working area (a variable that must be defined in the inventory aims) the inventory method will be different (Table 1).

Limited areas are here considered as territories with an area smaller than $3000-4000 \mathrm{~km}^{2}$, which generally corresponds to a typical protected area or a municipality. Limited areas should have a suitable size to allow the inventory team to do systematic fieldwork in the whole area in a time- and cost-effective way. On the contrary, large areas are territories with dozens or hundreds of thousands of square kilometres, typically the size of a country or a state (in federated countries).

The first step of a geosite's inventory is similar for both types of areas. It consists of a literature review of all geological data published about the area under study (geological maps, reports, theses, peer-reviewed papers, etc.). The literature review is important for knowing the geological setting of the area and for setting up a list of potential geosites refereed in the literature, such as sites where relevant data were obtained, stratotypes, stops of scientific fieldtrips, key outcrops for certain formations, etc. This list of potential geosites can also be enriched with the advice of experts that have developed research in the area. For inventories in large areas, this information will be used to help define geological frameworks.

The inventory of geosites based on geological frameworks started in Europe during the 1980s through the action of

Table 1 Sequential tasks for geosite inventory in limited and large areas, taking only into consideration scientific value (SV). However, after geosites are selected, their potential educational and touristic uses can also be assessed

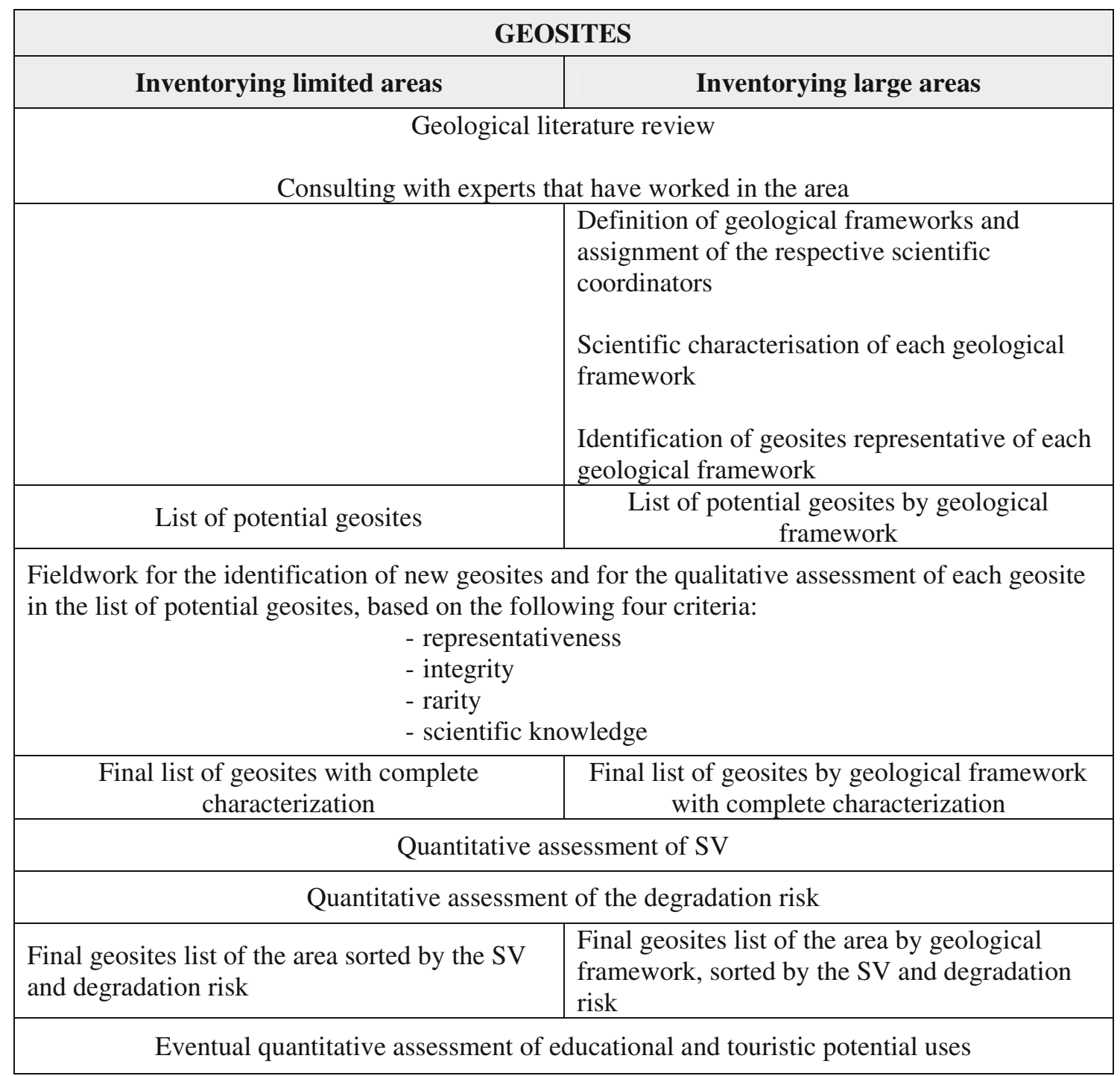


ProGEO - The European Association for the Conservation of the Geological Heritage (Erikstad 2008; Wimbledon 2011 and references therein). The geological frameworks of a territory are the main themes related to geoscience materials and/or processes that allow a better understanding of the geological history of that same territory. Geological frameworks should represent the main chapters of the Earth's history that left evidence in the territory under study. The definition of geological frameworks must be made with the consensus of the geoscientific community. Geological frameworks may not have geographical continuity within the area and they can also exist in contiguous territories, i.e. they may not be exclusive to the area under analysis. Each category must have a scientific coordinator and the collaboration of other experts on the theme. Each scientific coordinator is responsible for the compilation of a list of potential geosites that may represent the framework.

The next step consists of fieldwork with two main aims: to identify and characterise all the sites included in the list of potential geosites and to recognise new potential geosites. Fieldwork in large areas should assess if potential geosites have the necessary characteristics to be considered geosites for the corresponding framework. During fieldwork, each potential geosite must be qualitatively evaluated using the following criteria:

(i) Representativeness: concerning the appropriateness of the geosite to illustrate a geological process or feature that brings a meaningful contribution to the understanding of the geological topic, process, feature, or geological framework

(ii) Integrity: related to the present conservation status of the geosite, taking into account both natural processes and human actions

(iii) Rarity: number of geosites in the study area presenting similar geological features

(iv) Scientific knowledge: based on the existence of scientific data already published about the geosite.

The application of these criteria can imply the removal of potential geosites from the list because they do not comply with the criteria. A selection of geosites with scientific value should highlight occurrences in the study area that better represent a certain geological material or process, that are in the best possible conservation status, that show rare features, and where significant scientific data have been obtained and published. If the three first criteria present no controversy, the same cannot be said when considering the fourth one. The inexistence of scientific literature about a certain geological occurrence does not necessarily imply that it has no scientific value. It may just mean that the occurrence is new to the scientific community and that no significant scientific work has been done so far. In spite of the validity, or not, of this argument, we should not forget that geological occurrences which have originated scientific publications always have a particular relevance. In geosite inventorying and assessment, there are no infallible criteria or methods. There is always a certain subjectivity that should be minimised by the good scientific background of the geoscientists involved in these tasks and by the use of a solid methodology.

After fieldwork, the list of potential geosites is converted into a definitive list of geosites for the area under study. Each final geosite must be characterised using a form containing the following data:

(i) Name of the geosite (in order to facilitate a quick and easy identification of all geosites, the name of a geosite should include the main geological feature and a geographical reference, for instance 'Denver dinosaurs' or 'Iguaçu waterfalls')

(ii) Geographical location (including GPS coordinates)

(iii) Owner (public or private)

(iv) Legal protection (if any)

(v) Accessibility

(vi) Fragility and vulnerability (see "Quantitative Assessment of Degradation Risk")

(vii) Geological description

(viii) Most remarkable geological features which justify the need to considerer the occurrence as a geosite

(ix) Geological framework (when applicable)

(x) Eventual limitations to its scientific use (need for permission for sampling, seasonal access restrictions due to snow, tides, etc.).

While most of these data fields can be filled in during the fieldwork stage, others can only be completed in the office.

Once the inventory of geosites is concluded, it is necessary to obtain information that will allow the establishment of priorities in geosite management and to do a quantitative assessment of the geosites' scientific value and degradation risk (DR) following the methods described in "Methods for the Quantitative Assessment of Geological and Geodiversity Sites". The combination of high scientific value with a high DR justifies an urgent priority in a geoheritage management action plan.

As previously stated, $\mathrm{SV}$ is the solve factor that can validate a geosite. However, in order to increase the impact of a geosite in society, each geosite in the inventory can be assessed for its potential use for education and/or tourism. Nevertheless, the conservation of geodiversity elements that were considered exceptional in each geosite is absolutely vital. There is no geosite if the geological relevance is irremediably affected. This means that if there is a high risk of deterioration of the geodiversity elements, no educational and/or touristic uses should be implemented in a geosite. Therefore, geoheritage managers should decide wisely about the need to develop a geosites' assessment of the educational and/or potential uses. 
Inventory of Geodiversity Sites

As explained before, geodiversity sites correspond to geodiversity occurrences that have no significant scientific value. However, due to their relevant educational and/or touristic values, geodiversity sites should be conserved to allow a sustainable use of geodiversity by society. These geodiversity sites may also have a meaningful cultural significance for the identity of local communities. The inventory of geodiversity sites is usually done in limited areas and the proposed inventory method will not make any difference in what concerns the size of the study area. The proposed sequence of steps for the inventory of geodiversity sites is presented in Table 2 .

As with an inventory of geosites, the inventory of geodiversity sites begins with the review of the geological literature and the consultation of experts with work experience in the study area. If an inventory of geosites exists for the area, these geosites may also be included as potential geodiversity sites. For the inventory of sites with educational value, it is important to research which sites are already being used in educational activities. In the case of the inventory of sites with touristic value, it is also important to review touristic documentation on the area (leaflets, websites, etc.) in order to add some more locations to the potential list of geodiversity sites. It is usual to see certain locations being used by tourism managers and advertised as touristic attractions when, in fact, they are notable evidence of geodiversity elements, usually with geomorphological significance.

After a list of potential geodiversity sites has been made, fieldwork is necessary to identify and characterise all the sites and to recognise new potential sites. Each site with potential educational value (EV) must be qualitatively evaluated using the following four criteria:

(i) Didactic potential: related to the capacity of a geological feature to be easily understood by students of different educational levels (primary and secondary schools, universities).

(ii) Geological diversity: number of different types of geodiversity elements present in the same site

(iii) Accessibility: conditions of access to the site in terms of difficulty and time spent on foot for ordinary students

(iv) Safety: related to the visiting conditions, taking into consideration minimum risk for students.

For the selection of geodiversity sites with high EV, occurrences should have different geological features which can be easily understood by students of different levels of education, with comfortable and quick access and where students may observe the site under good safety conditions. These criteria must take into account the average age of the majority of students that will use the site. For instance, the accessibility

Table 2 Sequential tasks for the inventory of geodiversity sites with educational and/or touristic values

\begin{tabular}{|c|c|}
\hline \multicolumn{2}{|c|}{ GEODIVERSITY SITES } \\
\hline \multicolumn{2}{|c|}{ Educational Value (EV) } \\
\hline \multicolumn{2}{|c|}{ Tourism Value (TV) } \\
Consulting with experts that worked in the area before
\end{tabular}


conditions can be distinctly different if a site is to be used by young children or by university students.

Similarly, geodiversity sites with potential tourism value (TV) should be qualitatively evaluated using the following four criteria:

(i) Scenery: associated with the visual beauty of the geological occurrence (landscape or outcrop)

(ii) Interpretative potential: related to the capacity of a geological feature to be easily understood by lay people

(iii) Accessibility: conditions of access to the site in terms of difficulty and time of the walk for the general public

(iv) Safety: related to the visiting conditions, taking into consideration minimum risk for visitors.

Geodiversity sites with high TV should present visual beauty enjoyable by the majority of the public, with geological features that can be easily observed and understood by non-specialists under good safety conditions, and with comfortable and quick access.

The list of potential geodiversity sites is converted into a definitive list after fieldwork. Each geodiversity site must be characterised using a form containing the following data:

(i) Name of the geodiversity site (as with the name of geosites, it is recommended that the name of a geodiversity site should include the type of geological element and a geographical identification)

(ii) Geographical location (including GPS coordinates)

(iii) Owner (public or private)

(iv) Legal protection (if any)

(v) Accessibility

(vi) Fragility and vulnerability (see "Quantitative Assessment of Degradation Risk")

(vii) Geological description

(viii) Geodiversity features with potential educational and/or touristic uses

(ix) Eventual links with ecological and cultural assets

(x) Eventual use limitations (need to pay entrance fee, carrying capacity restrictions, seasonal limitations, etc.)

(xi) Safety conditions (present conditions for students and tourists taking into account their safety)

(xii) Observation conditions (of the main geodiversity elements).

Once the inventory of the geodiversity sites is concluded, a quantitative assessment should be made in order to obtain important data for proper site management, just as in the geosite inventory. The assessment of the potential educational and/or touristic uses and of sites' degradation risk is essential for defining a correct strategy. Obviously, managers should consider sites with low degradation risk and high potential for education and tourism as the top priority.

\section{Methods for the Quantitative Assessment of Geological and Geodiversity Sites}

The research about numerical assessment of sites has been under development for the last decade, but the geoscientific community has not yet reached a general accepted method. Usually, quantitative methods are based on several criteria and respective indicators to which different scores or parameters may be assigned (Cendrero 1996a, b; Coratza and Giusti 2005; Pralong and Reynard 2005; Pereira et al. 2007; Reynard et al. 2007; Bruschi and Cendrero 2009; Reynard 2009; Pereira and Pereira 2010; Bruschi et al. 2011; Fassoulas et al. 2012; Pereira and Pereira 2012; Bollati et al. 2013). The aim of a quantitative assessment is to decrease the subjectivity associated with any evaluation procedure. The result of this numerical assessment is a sorted list of sites, which is a powerful tool for the establishment of management priorities. Sites with higher value and higher degradation risk should be given top priority. The quantitative assessment of sites works better when dozens of them are being evaluated. For small areas with just a few sites, these procedures have no practical results and may be discarded.

The number of criteria in quantitative assessments should be limited, as shown by Bruschi et al. (2011). These authors have shown that a high number of criteria do not necessarily imply a more accurate assessment. Due to the fact that there are distinct criteria for different sites' values (scientific, educational, tourism), their quantitative assessment must be done separately. In fact, there are different perspectives in the assessment of the three types of values. Concerning the scientific value, it is expected that the scientific significance of the occurrence, regardless of its immediate potential use, be evaluated. A geosite with scientific value should be conserved for what it represents, regardless of the potential scientific use that it may provide in the short term. In what concerns educational and touristic value, what is really at stake is the potential educational and touristic use of the sites. These types of value are intrinsically related to the site's use; it only makes sense to conserve a site with educational value if it will be effectively used as an educational resource. A similar justification can be made for sites with touristic value: their conservation is deeply related to their use as tourist attractions.

Several criteria can be adapted to the real conditions that exist in the area of study. It is an advantage if quantitative assessments are done by the same geoscientists that have participated in the selection of geosites and geodiversity sites because they are more familiar with certain specificities of the sites under evaluation. As a consequence, the results of the quantitative assessment can only be used for comparative reasons in a set of sites that occur in the area of study. Obviously, sites assessed with different methods cannot be compared.

Another remark is that, for very small areas, some of the criteria are useless because the respective score is the same for 
all sites, which does not contribute to the required site discrimination. For instance, population density (a criterion, used to assess the PEU) has the same value for all sites if a small area is being studied. Hence, for very small areas with very few sites, there is no need to do a quantitative assessment of the value/use of sites.

Even if a number comes out as the final result of a quantitative assessment, this does not mean that it is not necessary to proceed with a critical and detailed analysis of the results. Sometimes, the final result may place a certain site at the bottom of the list but the inventory coordinator intuitively knows that the same site is significant in the area. These kinds of contradictions need to be explained and interpreted. The scientific coordinator of the whole process should have the final and definitive word about the sorted list of sites for the area under consideration.

As stated before, the present methodological proposal for the quantitative assessment of geosites is the result of a survey and compilation of the best published practices (see previous references in this section) and the author's own experience.

\section{Quantitative Assessment of Scientific Value}

For the quantitative assessment of the SV of geosites, seven criteria can be used:

A. Representativeness: capacity of a geosite to illustrate geological elements or processes (related to the geological framework under consideration when applicable)

B. Key locality: importance of a geosite as a reference or model for stratigraphy, palaeontology, mineralogy, etc.

C. Scientific knowledge: the existence of published scientific studies about the geosite (related to the geological framework under consideration when applicable) reflects the SV given by the geoscientific community

D. Integrity: related to the conservation status of the main geological elements (related to the geological framework under consideration when applicable); the better the integrity, the higher the SV

E. Geological diversity: a high number of different geological elements with scientific interest (related to the geological framework under consideration when applicable) in a geosite implies a higher SV

F. Rarity: a small number of similar geosites in the area of study (representing the geological framework under consideration when applicable) increases the SV

G. Use limitations: the existence of obstacles that may be problematic for the regular scientific use of the geosite has impacts on the geosite's SV.

All criteria from A to $F$ are intrinsically related to the geological characteristics of the geosite, which makes sense once what is being evaluated is the scientific value of the geosite. However, criterion $\mathrm{G}$ is not related to value but to potential use. The inclusion of this criterion is justified due to the fact that part of the scientific value of a geosite is related to the possibility of using the site for present and future research. Therefore, criterion $\mathrm{G}$ intends to assess if there are limitations to scientific research.

Each geosite is ranked 1, 2, or 4 points in accordance with the indicators for each criterion (Table 3 ). An indicator can also be ranked zero if appropriate. There is no indicator with 3 points in order to better distinguish geosites ranked with 4 points. The final SV is a weighted sum of the seven criteria, as expressed in Table 4. Usually, weight distribution is a source of discussion. Further research is needed to fully address this issue.

Different weights correspond to the relative importance of the diverse criteria. For the SV evaluation, representativeness is considered the most important criterion (30\%), immediately followed by the key locality ( $20 \%)$. The geological diversity and scientific knowledge criteria are the least important (5\% each). In fact, the inexistence of scientific publications about a certain geosite does not necessarily represent a low $\mathrm{SV}$, as stated before. It may just mean that it is a recent discovery and no studies have yet been published. It may also represent a geosite located in one area with no tradition in geological studies or with few research teams operating in it.

As mentioned before, it is important and even mandatory to make a final reflection about the results of any quantitative assessment.

A geosite has a maximum SV when it is the best representative occurrence for a certain geological feature or geological framework, and a rare well-known international reference with publications about it, and when it presents several wellconserved geological features with scientific relevance that are easily available for future research.

\section{Quantitative Assessment of Potential Educational Use}

The quantitative assessment of potential educational use (PEU) is based on 12 criteria:

A. Vulnerability - the existence of geological elements that can be destroyed by students decreases the EV of the site

B. Accessibility - the easier and shorter the walk between the means of transportation and the site is, the higher the EV

C. Use limitations - the existence of obstacles that may be problematic for the development of educative activities has an impact on the site's EV

D. Safety - when the field activity can be carried out under low risk conditions for students, the EV of the site increases

E. Logistics - the existence of facilities to receive students, such as accommodation, food, and toilets, increases the site's EV 
Table 3 Criteria, indicators, and parameters used for the quantitative assessment of the scientific value of geosites

Scientific value (SV)

Criteria/indicators

Parameters

A. Representativeness

The geosite is the best example in the study area to illustrate elements or processes, related with the geological framework under consideration (when applicable)

The geosite is a good example in the study area to illustrate elements or processes, related with the geological framework under consideration (when applicable)

The geosite reasonably illustrates elements or processes in the study area, related with the geological framework under consideration 1 point (when applicable)

B. Key locality

The geosite is recognised as a GSSP or ASSP by the IUGS or is an IMA reference site

4 points

The geosite is used by international science, directly related with the geological framework under consideration (when applicable)

2 points

The geosite is used by national science, directly related with the geological framework under consideration (when applicable)

1 point

C. Scientific knowledge

There are papers in international scientific journals about this geosite, directly related with the geological framework under consideration 4 points (when applicable)

There are papers in national scientific publications about this geosite, directly related with the geological framework under consideration 2 points (when applicable)

There are abstracts presented in international scientific events about this geosite, directly related with the geological framework under 1 point consideration (when applicable)

D. Integrity

The main geological elements (related with the geological framework under consideration, when applicable) are very well preserved 4 points

Geosite not so well preserved, but the main geological elements (related with the geological framework under consideration, when 2 points applicable) are still preserved

Geosite with preservation problems and with the main geological elements (related with the geological framework under consideration, 1 point when applicable) quite altered or modified

E. Geological diversity

Geosite with more than three types of distinct geological features with scientific relevance

Geosite with three types of distinct geological features with scientific relevance

4 points

Geosite with two types of distinct geological features with scientific relevance

2 points

1 point

F. Rarity

The geosite is the only occurrence of this type in the study area (representing the geological framework under consideration, when 4 points applicable)

In the study area, there are two to three examples of similar geosites (representing the geological framework under consideration, when 2 points applicable)

In the study area, there are four to five examples of similar geosites (representing the geological framework under consideration, when 1 point applicable)

G. Use limitations

The geosite has no limitations (legal permissions, physical barriers,...) for sampling or fieldwork

4 points

It is possible to collect samples and do fieldwork after overcoming the limitations

2 points

Sampling and fieldwork are very hard to be accomplished due to limitations difficult to overcome (legal permissions, physical 1 point barriers,...)

F. Density of population - the existence of a population near the site, potentially providing students who will use the site, increases its EV

G. Association with other values - the existence of other natural or cultural elements associated with the site may justify interdisciplinary fieldtrips and increase the EV of the site

H. Scenery-represents the beauty of the geological elements that could stimulate students' interest for the site and thus increases its EV
I. Uniqueness - concerns the distinctiveness and the rarity of the geodiversity element that could promote students' interest for the site and raise its $\mathrm{EV}$

J. Observation conditions - the better the conditions for observation of all the geodiversity elements on the site, the higher its EV

K. Didactic potential - the use of the site by students of different education levels increases the EV of the site

L. Geological diversity — a high number of different geological elements with didactic potential increases the $\mathrm{EV}$ of the site. 
Table 4 Weights for the different criteria used for the assessment of the scientific value of geosites

\begin{tabular}{lc} 
Scientific value (sv) & \\
\hline Criteria & Weight (\%) \\
\hline A. Representativeness & 30 \\
B. Key locality & 20 \\
C. Scientific knowledge & 5 \\
D. Integrity & 15 \\
E. Geological diversity & 5 \\
F. Rarity & 15 \\
G. Use limitations & 10 \\
Total & 100 \\
\hline
\end{tabular}

Each criterion is scored from 1 to 4 according to the indicators explained in Table 5; zero can be given to any criterion. The final educational potential use is the weighted sum of all 12 criteria (Table 6).

A site has a higher PEU when the geodiversity elements are resistant to eventual destruction caused by students (low vulnerability) and when they can be easily observed by students of all school levels (from primary to university students). This type of site can also be easily reached by means of transportation and provides safe conditions for particular types of user that might have imprudent behaviour, particularly those in certain age groups.

\section{Quantitative Assessment of Potential Touristic Use}

The quantitative assessment of the potential touristic use (PTU) considers 13 criteria (Table 5):

A. Vulnerability: the existence of geodiversity elements that can be destroyed by visitors decreases the TV of the site

B. Accessibility: the easier and shorter the walk between the visitors' transportation (bus, car, etc.) and the site is, the higher the TV

C. Use limitations: the existence of obstacles that may be problematic for the development of touristic activities has an impact on the site's TV

D. Safety: if the visit can be made under low risk conditions for visitors, the site's TV increases

E. Logistics: the inexistence of facilities for receiving tourists, such as information centres, accommodation, food, and toilets, decreases the site's TV

F. Density of population: the existence of towns/cities near the geosite as a potential source of visitors to the site increases its TV

G. Association with other values: the occurrence of other natural or cultural elements associated with the site may increase the number of potential visitors and consequently the TV of the site

H. Scenery: represents the beauty of the geodiversity element that might attract visitors, increasing the site's TV

I. Uniqueness: concerns the distinctiveness and the rarity of the geodiversity elements that could stimulate a sense of satisfaction for the visitors

J. Observation conditions: the better the observation of all the geodiversity elements of the geosite, the higher its TV

$\mathrm{K}$. Interpretative potential: related to the capacity of a geodiversity feature to be easily understood by people with no geological background, i.e. typical members of the general public

L. Economic level: the high level of income of people living near the site suggests a higher probability of it being visited

M. Proximity of recreational areas: a touristic visit to a site may benefit from the existence of well-known tourist attractions in the surrounding area.

Again, each criterion is scored from 1 to 4 points (zero is also possible) and the final evaluation of the touristic value is the result of the weighted sum of the scores (Table 6).

A site has a high PTU when the geological elements have a remarkable aesthetic relevance (usually geomorphological elements are the ones with a higher potential to be aesthetically appreciated by the general public) and can be easily understood by persons with no geoscientific background, as well as being associated with a low risk of degradation by anthropic activity (low vulnerability). Obviously, the existence of good facilities and visiting conditions are essential assets for touristic use of a site. However, it should be noted that this assessment is done to evaluate the potential touristic use of a site and, if this potential is high, there is a justification for building new or better facilities to improve visiting conditions.

\section{Quantitative Assessment of Degradation Risk}

As discussed before, the numerical evaluation of site DR as a complement to the assessment of a site's value is of crucial importance for the preparation and implementation of a management plan. The conjugation of the value of a certain site and its DR is essential for establishing priorities in any sites' action plan. Fuertes-Gutiérrez and Fernández-Martínez (2012) present the DR as a combination of vulnerability, fragility, and other factors, such as accessibility, dimensions, proximity to human settlements, public influx, and present or potential threats. The same authors in a previous work (Fuertes-Gutiérrez and Fernández-Martínez 2010) clarify the concept of vulnerability as being 'the risk of destruction due to human activity. Sites are vulnerable when intensive human activity affects them or when their dimensions are so small that any human activity (even some which are not so aggressive) can cause damage'. These authors clearly distinguish the vulnerability concept from the fragility one: 'The fragility of a site 
measures its degradation risk under present natural conditions, i.e., without the intervention of Man. A site is fragile when a process of either a rapid (human scale) damage or destruction occurs'. Both concepts are used with the same meaning in the present work.
The proposal for the quantitative assessment of site DR was developed taking into consideration the author's experience and the best practices published in recent years, including Cendrero (1996a; b), Brilha (2005), Carcavilla et al. (2007), Reynard et al. (2007), García-Cortés and Carcavilla Urquí

Table 5 Criteria, indicators, and parameters used for the quantitative assessment of the potential educational and touristic uses. Ten criteria (A-J) are shared between these two types of uses. Two more criteria (K-L) are used to assess PEU and three (K-M) for PTU

\section{POTENTIAL EDUCATIONAL AND TOURISTIC USES

\section{A. Vulnerability}

The geological elements of the geosite present no possible deterioration by anthropic activity

There is the possibility of deterioration of secondary geological elements by anthropic activity

There is the possibility of deterioration of main geological elements by anthropic activity

There is the possibility of deterioration of all geological elements by anthropic activity

\section{B. Accessibility}

Site located less than $100 \mathrm{~m}$ from a paved road and with bus parking

Site located less than $500 \mathrm{~m}$ from a paved road

Site accessible by bus but through a gravel road

Site with no direct access by road but located less than $1 \mathrm{~km}$ from a road accessible by bus

\section{4 points \\ 3 points \\ 2 points \\ 1 point}

\section{Use limitations}

The site has no limitations to be used by students and tourists

The site can be used by students and tourists but only occasionally

The site can be used by students and tourists but only after overcoming limitations (legal, permissions, physical, tides, floods, ...)

The use by students and tourists is very hard to be accomplished due to limitations difficult to overcome (legal, permissions, physical, tides, floods, ...)

\section{Safety}

Site with safety facilities (fences, stairs, handrails, etc.), mobile phone coverage and located less than $5 \mathrm{~km}$ from emergency services Site with safety facilities (fences, stairs, handrails, etc.), mobile phone coverage and located less than $25 \mathrm{~km}$ from emergency services Site with no safety facilities but with mobile phone coverage and located less than $50 \mathrm{~km}$ from emergency services

Site with no safety facilities, no mobile phone coverage and located more than $50 \mathrm{~km}$ from emergency services

\section{E. Logistics}

Lodging and restaurants for groups of 50 persons less than $15 \mathrm{~km}$ away from the site

Lodging and restaurants for groups of 50 persons less than $50 \mathrm{~km}$ away from the site

Lodging and restaurants for groups of 50 persons less than $100 \mathrm{~km}$ away from the site

Lodging and restaurants for groups less than 25 persons and less than $50 \mathrm{~km}$ away from the site

1 point

\section{F. Density of population}

Site located in a municipality with more than 1000 inhabitants $/ \mathrm{km}^{2}$

Site located in a municipality with $250-1000$ inhabitants $/ \mathrm{km}^{2}$

Site located in a municipality with $100-250$ inhabitants $/ \mathrm{km}^{2}$

Site located in a municipality with less than 100 inhabitants $/ \mathrm{km}^{2}$

\section{G. Association with other values}

Occurrence of several ecological and cultural values less than $5 \mathrm{~km}$ away from the site

Occurrence of several ecological and cultural values less than $10 \mathrm{~km}$ away from the site

Occurrence of one ecological value and one cultural value less than $10 \mathrm{~km}$ away from the site

Occurrence of one ecological or cultural value less than $10 \mathrm{~km}$ away from the site

\section{H. Scenery}

Site currently used as a tourism destination in national campaigns

Site occasionally used as a tourism destination in national campaigns

Site currently used as a tourism destination in local campaigns

Site occasionally used as a tourism destination in local campaigns

\section{Uniqueness}

The site shows unique and uncommon features considering this and neighbouring countries

The site shows unique and uncommon features in the country

The site shows common features in this region but they are uncommon in other regions of the country

The site shows features rather common in the whole country

\section{J. Observation conditions}

All geological elements are observed in good conditions

There are some obstacles that make difficult the observation of some geological elements

There are some obstacles that make difficult the observation of the main geological elements

There are some obstacles that almost obstruct the observation of the main geological elements 
Table 5 (continued)

\section{POTENTIAL EDUCATIONAL USE}

K. Didactic potential

The site presents geological elements that are taught in all teaching levels

The site presents geological elements that are taught in elementary schools

The site presents geological elements that are taught in secondary schools

The site presents geological elements that are taught in the university

\section{Geological diversity}

More than 3 types of geodiversity elements occur in the site (mineralogical, palaeontological, geomorphological, etc.)

There are 3 types of geodiversity elements in the site

There are 2 types of geodiversity elements in the site

There is only 1 type of geodiversity element in the site

\section{POTENTIAL TOURISTIC USE}

\section{K. Interpretative potential}

4 points und

2 points

1 point

understand the geological elements of the site

The site presents geological elements only understandable to geological experts

\section{Economic level}

4 points
3 points
2 points
1 point

The site is located in a municipality with a household income at least the double of the national average

The site is located in a municipality with a household income

higher than the national average

The site is located in a municipality with a household income

similar to the national average

The site is located in a municipality with a household income

lower than the national average

\section{Proximity of recreational areas}

Site located less than $5 \mathrm{~km}$ from a recreational area or tourist attraction

Site located less than $10 \mathrm{~km}$ from a recreational area or tourist attraction

Site located less than $15 \mathrm{~km}$ from a recreational area or tourist attraction

Site located less than $20 \mathrm{~km}$ from a recreational area or tourist

attraction

4 points
3 points
2 points
1 point

4 points

3 points

2 points

1 point

4 points

3 points

2 points

1 point
(2009), Lima et al. (2010), Pereira and Pereira (2010), and Fassoulas et al. (2012).

Table 6 Weights for the different criteria used for the assessment of the potential educational and touristic uses

Potential use

\begin{tabular}{|c|c|c|c|}
\hline \multicolumn{2}{|l|}{ Educational } & \multicolumn{2}{|l|}{ Touristic } \\
\hline Criteria & Weight & Criteria & Weight \\
\hline A. Vulnerability & 10 & A. Vulnerability & 10 \\
\hline B. Accessibility & 10 & B. Accessibility & 10 \\
\hline C. Use limitations & 5 & C. Use limitations & 5 \\
\hline D. Safety & 10 & D. Safety & 10 \\
\hline E. Logistics & 5 & E. Logistics & 5 \\
\hline F. Density of population & 5 & F. Density of population & 5 \\
\hline $\begin{array}{l}\text { G. Association with other } \\
\text { values }\end{array}$ & 5 & $\begin{array}{l}\text { G. Association with other } \\
\text { values }\end{array}$ & 5 \\
\hline H. Scenery & 5 & H. Scenery & 15 \\
\hline I. Uniqueness & 5 & I. Uniqueness & 10 \\
\hline J. Observation conditions & 10 & J. Observation conditions & 5 \\
\hline K. Didactic potential & 20 & $\mathrm{~K}$. Interpretative potential & 10 \\
\hline \multirow[t]{2}{*}{ L. Geological diversity } & 10 & L. Economic level & 5 \\
\hline & & $\begin{array}{l}\text { M. Proximity of } \\
\text { recreational areas }\end{array}$ & 5 \\
\hline Total & 100 & Total & 100 \\
\hline
\end{tabular}

The DR assessment is based on five criteria:

A. Deterioration of geological elements: reflects the possibility of loss of geological elements in the site as a consequence of (i) its fragility, namely its intrinsic characteristics (size of the geological element, ease of obtaining samples, resistance of the rock, etc.) and natural actions (susceptibility to erosion, intensity of erosional agents, etc.) and (ii) its vulnerability to anthropic actions (tourism, agriculture, urban development, vandalism, etc.)

B. Proximity to areas/activities with potential to cause degradation: mining, industrial facilities, recreational areas, roads, urban areas, etc.

C. Legal protection: related to the location of the site in an area with any type of legal protection (direct or indirect). Access control refers to the existence of obstacles, such as restrictions by the owner, fences, need to pay entrance fees, mining activities

D. Accessibility: reflects the conditions of access to the site for the general public (not considering disabled people). A site with easy access is more likely to be damaged by visitors' misuse than one with difficult access

E. Density of population: reveals the number of persons that live near the site and that can cause potential deterioration to the site due to inappropriate use (vandalism, theft, etc.). 
Table 7 Criteria, indicators, and parameters used for the quantitative assessment of degradation risk (DR) of sites

\begin{tabular}{ll}
\hline Degradation risk & \\
\hline Criteria/indicators & Parameters \\
A. Deterioration of geological elements & \\
Possibility of deterioration of all geological elements & 4 points \\
Possibility of deterioration of the main geological elements & 3 points \\
Possibility of deterioration of secondary geological elements & 2 points \\
Minor possibility of deterioration of secondary geological elements & 1 point \\
B. Proximity to areas/activities with potential to cause degradation & \\
Site located less than 50 m of a potential degrading area/activity & 4 points \\
Site located less than $200 \mathrm{~m}$ of a potential degrading area/activity & 3 points \\
Site located less than $500 \mathrm{~m}$ of a potential degrading area/activity & 2 points \\
Site located less than 1 km of a potential degrading area/activity & 1 point \\
C. Legal protection & \\
Site located in an area with no legal protection and no control of access & 4 points \\
Site located in an area with no legal protection but with control of access & 3 points \\
Site located in an area with legal protection but no control of access & 2 points \\
Site located in an area with legal protection and control of access & 1 point \\
D. Accessibility & \\
Site located less than $100 \mathrm{~m}$ from a paved road and with bus parking & 4 points \\
Site located less than $500 \mathrm{~m}$ from a paved road & 3 points \\
Site accessible by bus through a gravel road & 2 points \\
Site with no direct access by road but located less than $1 \mathrm{~km}$ from a road accessible by bus & 1 point \\
E. Density of population & \\
Site located in a municipality with more than 1000 inhabitants $/ \mathrm{km}{ }^{2}$ & 4 points \\
Site located in a municipality with $250-1000$ inhabitants $/ \mathrm{km}^{2}$ & 3 points \\
Site located in a municipality with $100-250$ inhabitants $/ \mathrm{km}^{2}$ & 2 points \\
Site located in a municipality with less than 100 inhabitants $/ \mathrm{km}{ }^{2}$ & 1 point \\
\hline
\end{tabular}

As before, each criterion is scored between 1 and 4 points (zero is also possible) (Table 7). The final DR value results from the weighted sum of the scores given to each criterion (Table 8). For management purposes, it might be useful to have the DR classified as low, moderate, and high (Table 9).

It is worth mentioning that criteria D (accessibility) and E (density of population) are used both in the evaluation of the educational and touristic value of sites and the DR. However, these criteria are considered in a different manner. To assess

Table 8 Weights for the different criteria used for the assessment of degradation risk (DR) of sites

Degradation risk

\section{Criteria}

Weight

A. Deterioration of geological elements

B. Proximity to areas/activities with potential to cause degradation

C. Legal protection

D. Accessibility

E. Density of population the value of a site, good accessibility is considered an advantage because it allows a higher number of visitors. A high number of persons living near a site are also considered an advantage for potential educational and touristic use. However, good accessibility to a site is also a risk in terms of vulnerability because the more people that visit the site, the higher the risk that the site will be damaged. The same idea applies to population density: more people living near a site increase the probability of human-induced deterioration.

A site has maximum DR when its main characteristic geological elements have a high probability of being damaged either by natural or anthropic factors, when the site is not under legal protection, and when it is located near a potentially harmful area or activity.

Table 9 Considering the final value, degradation risk (DR) can be classified in three classes: low, moderate, and high

\begin{tabular}{ll}
\hline Total weighted & Degradation risk \\
\hline$<200$ & Low \\
$201-300$ & Moderate \\
$301-400$ & High \\
\hline
\end{tabular}




\section{Geodiversity Inventory in Geoparks}

Geoparks are becoming quite popular in certain regions of the world. Geoparks are well-defined territories with a development plan that aims to integrate the conservation of geological heritage (and other natural assets) with the preservation of the cultural identity of local communities. Based on the conservation of natural and cultural assets and on the promotion of education and geotourism, geoparks are tools designed to promote the sustainable development of local populations (Patzak and Eder 1998; Eder 1999; Eder and Patzak 2004; Zouros 2004; McKeever et al. 2010). A Global Network of National Geoparks (GGN), set up under the auspices of UNESCO in 2004, today integrates 111 geoparks distributed in 32 countries, mostly in Europe and Asia. In order to be accepted in this network, candidate territories must apply and show that they fulfil a rather complete set of requirements. One of these requirements is the inventory of geological heritage, a key asset of any geopark.

Any GGN geopark must prove that the geodiversity of its territory is represented by geosites of international relevance. In order to achieve this requirement, a solid inventory of geosites must be made in the territory, highlighting the significant scientific value of the geodiversity elements. The inventory and management of geodiversity sites is also of highest importance for all geoparks. Therefore, in order to prepare a territory to become a geopark, several steps are proposed to make a sound geodiversity characterisation:

1. General description of geodiversity with an explanation of the geological and geomorphological setting of the territory

2. Inventory and quantitative assessment of geosites' scientific value and degradation risk

3. Quantitative assessment of educational and touristic potential uses of geosites

4. Inventory of geodiversity sites

5. Quantitative assessment of educational and touristic potential uses of geodiversity sites, together with the degradation risk evaluation.

Based on the results of the inventory of geoheritage and geodiversity sites and respective numerical assessment, geopark managers are capable of preparing an adequate geoconservation action plan that constitutes a solid background tool for any geopark. This geoconservation action plan should define priorities for the management of geosites and geodiversity sites, which ones will be used as educational and touristic resources, what kind of infrastructures are needed, etc.

Managers of protected areas can also apply this same proposal of geodiversity characterisation to guarantee the correct management of their parks.

\section{Conclusion}

To select which geodiversity elements are exceptional in a certain area is not an easy task. If the area corresponds to a whole country with high geological and geomorphological diversity, the scenario is even more challenging. This is one of the reasons that justifies the need for a solid method for the inventory of geosites and geodiversity sites. Nowadays, it is increasingly recognised that the selection of the most valued sites for protection and management is of paramount importance both for science and other societal uses.

Starting from the best examples published in the literature and based on the author's experience, the present work proposes an inventory method for geological heritage and geodiversity sites. Geological heritage should be recognised for its scientific value, and, based on this fact, four criteria should be used to select geosites: representativeness, integrity, rarity, and scientific knowledge. In order to select geodiversity sites with educational and touristic value, two other sets of four criteria should be used: didactic potential, geological diversity, accessibility, and safety (for sites with educational value) and scenery, interpretative potential, accessibility, and safety (for sites with touristic value). It should be highlighted that the use of specific criteria for a certain type of value is particularly important due to the fact that it will allow the much more accurate selection of sites.

In areas with a large number of inventoried sites, a quantitative assessment of their SV, PEU, and PTU, together with DR, constitutes an important asset for management purposes. In fact, this assessment has two perspectives: it tries to evaluate the scientific value of sites and the potential educational and touristic use of sites, not their value. This difference is due to the fact that a geosite should be preserved for its scientific value independently of its effective immediate use, which is not the case for sites with educative and touristic values where their protection is only justified if they are to be used for those purposes. Seven criteria are proposed for the numerical assessment of scientific value: representativeness, key locality, scientific knowledge, integrity, geological diversity, rarity, and use limitations. The evaluation of the educational and tourism potential uses shares ten criteria: vulnerability, accessibility, use limitations, safety, logistics, density of population, association with other values, scenery, uniqueness, and observation conditions. For PEU, two more criteria can be used: didactic potential and geological diversity. In the evaluation of PTU, three other criteria are considered: interpretative potential, economic level, and proximity of recreational areas. Each criterion is described by several indicators and each indicator is quantified by a numerical parameter.

Whatever the type of value, different criteria have different weights which reflect distinctions in the relative importance of those same criteria. The same criterion can be used to assess 
different values but it is given diverse weights in the final evaluation.

Finally, the assessment of the degradation risk uses five criteria: deterioration of geological elements, proximity to areas/activities with the potential to cause degradation, legal protection, accessibility, and population density.

One of the main differences of the assessment proposal presented here in comparison to the majority of published proposals is that there is no determination of a final ranking or relevance score taking into account the results of the sites' values and DR. In fact, these two sets of data should not be computed together in a single formula to obtain a final score because they are independent of each other. The value of a site is not directly related to its vulnerability. Clearly, both aspects must be considered together in a management strategy, but there is no need to compute them simultaneously to obtain a final number.

The present methodological proposal for the inventory and numerical assessment of geological heritage and geodiversity sites can be applied in different geological and geomorphological settings, in different size areas, and under diverse legal contexts (parks, geoparks, areas with no protection, etc.). Obviously, some indicators have to be adapted for particular conditions. For instance, the distance values in some criteria or the density of population range can change for different countries.

In spite of the numerical assessment method used for geoheritage and geodiversity sites, it should be emphasised that a final reflection about the obtained results is essential. The scientific coordinator of the inventory should confirm the quality of the numerical results and search for eventual invalid ranking positions. The subjectivity inherent to an inventory and assessment of sites can never be totally eliminated. However, the method proposed in this paper can surely decrease some of this subjectivity.

Acknowledgments The author thanks Diamantino Pereira, Flavia Lima, and Paulo Pereira for fruitful discussions and insights; Teresa Mota for the English revision; and the reviewers for significant improvements of the first submitted version. This paper results of the research done at the University of Minho and at the Geology Centre of the University of Porto, partially founded by the Foundation for Science and Technology (Portugal), strategic project with reference PEst-OE/CTE/UI0039/2014.

\section{References}

Alexandrowicz Z, Kozlowski S (1999) From selected geosites to geodiversity conservation-Polish example of modern framework. In: Barettino D, Vallejo M, Gallego E (eds) Towards the balanced management and conservation of the geological heritage in the new millenium. Sociedad Geológica de España, Madrid, Spain, pp 40-44

Black GP, Gonggrijp GP (1990) Fundamental thoughts on Earth-science conservation. Jb. Geol. B.-A. Band 133, Heft 4:655-657
Bollati I, Smiraglia C, Pelfini M (2013) Assessment and selection of geomorphosites and trails in the Miage Glacier Area (Western Italian Alps). Environ Manag 51(4):951-967

Brilha J (2005) Património Geológico e Geoconservação: a Conservação da Natureza na sua Vertente Geológica. Palimage Editores, Viseu

Brilha J, Andrade C, Azerêdo A, Barriga FJAS, Cachão M, Couto $\mathrm{H}$, Cunha PP, Crispim JA, Dantas P, Duarte LV, Freitas MC, Granja MH, Henriques MH, Henriques P, Lopes L, Madeira J, Matos JMX, Noronha F, Pais J, Piçarra J, Ramalho MM, Relvas JMRS, Ribeiro A, Santos A, Santos V, Terrinha P (2005) Definition of the Portuguese frameworks with international relevance as an input for the European geological heritage characterisation. Episodes 28(3): $177-186$

Brilha J, Alcala L, Almeida A, Araújo A, Azerêdo A, Azevedo MR, Barriga F, Brum da Silveira A, Cabral J, Cachão M, Caetano P, Cobos A, Coke C, Couto H, Crispim J, Cunha PP, Dias R, Duarte LV, Dória A, Falé P, Ferreira N, Ferreira Soares A, Fonseca P, Galopim de Carvalho A, Gonçalves R, Granja H, Henriques MH, Kullberg JC, Kullberg MC, Legoinha P, Lima A, Lima E, Lopes L, Madeira J, Marques JF, Martins A, Martins R, Matos J, Medina J, Miranda R, Monteiro C, Moreira M, Moura D, Neto de Carvalho C, Noronha F, Nunes JC, Oliveira JT, Pais J, Pena dos Reis R, Pereira D, Pereira P, Pereira Z, Piçarra J, Pimentel N, Pinto de Jesus A, Prada S, Prego A, Ramalho L, Ramalho M, Ramalho R, Relvas J, Ribeiro A, Ribeiro MA, Rocha R, Sá A, Santos V, Sant'ovaia H, Sequeira A, Sousa M, Terrinha P, Valle Aguado B, Vaz N (2010) O inventário nacional do património geológico: abordagem metodológica e resultados. e-Terra, 18(1)

Browne MAE (2012) Geodiversity and the role of the planning system in Scotland. Scott Geogr J 128(3-4):266-277

Bruschi VM, Cendrero A (2009) Direct and parametric methods for the assessment of geosites and geomorphosites. In: Reynard E, Coratza P, Regolini-Bissig G (eds) Geomorphosites. Verlag Dr. Friedrich Pfeil, München. Section II, pp 73-88

Bruschi VM, Cendrero A, Albertos JAC (2011) A statistical approach to the validation and optimisation of geoheritage assessment procedures. Geoheritage 3(3):131-149

Carcavilla L, López Martínez J, Durán Valsero JJ (2007) Patrimonio geológico y geodiversidad: investigación, conservación, gestión y relación con los espacios naturales protegidos. Cuadernos del Museo Geominero, No. 7, IGME, Madrid

Carcavilla L, Durán JJ, Garcia-Cortés A, López-Martinez J (2009) Geological heritage and geoconservation in Spain: past, present, and future. Geoheritage 1(2-4):75-91

Cendrero A (1996a) El patrimonio geológico. Ideas para su protección, conservación y utilización. In: El patrimonio geológico. Bases para su valoración, protección, conservación y utilización. Serie Monografías del Ministerio de Obras Públicas, Transportes y Medio Ambiente. Ministerio de Obras Públicas, Transportes y Medio Ambiente, Madrid, pp 17-27

Cendrero A. (1996b) Propuestas sobre criterios para la clasificación y catalogación del patrimonio geológico. In: El patrimonio geológico. Bases para su valoración, protección, conservación y utilización. Serie Monografias del Ministerio de Obras Públicas, Transportes y Medio Ambiente. Ministerio de Obras Públicas, Transportes y Medio Ambiente, Madrid, pp 29-38

Coratza P, Giusti C (2005) Methodological proposal for the assessment of scientific quality of geomorphosites. II Quaternario, Italien. J Quat Sci 18(1):307-313

Díaz-Martínez E, Díez-Herrero A (2011) Los elementos biológicos y culturales de interés geológico: un patrimonio a conservar. In Fernández-Martínez E, Castaño de Luis R (eds) Avances y retos en la conservación del Patrimonio Geológico en España. Actas de la IX Reunión Nacional de la Comisión de Patrimonio Geológico (Sociedad Geológica de España), Universidad de León, pp 85-90 
Eder W (1999) "UNESCO GEOPARKS"— a new initiative for protection and sustainable development of the Earth's heritage. N Jb Geol Paläont (Abh) 214(1/2):353-358

Eder W, Patzak M (2004) Geoparks - geological attractions: a tool for public education, recreation and sustainable economic development. Episodes 27(3):162-164

Elízaga E, Gallego E, García-Cortés A (1994) Inventaire nacional des sites d'intérêt géologique en Espagne: méthodologie et déroulement. Mém Soc Geol France 165:103-109

Erikstad L (2008) History of geoconservation in Europe. In: Burek CV, Prosser CD (eds) The history of geoconservation, vol 300 . Geological Society, Special Publications, London, pp 249-256

Fassoulas C, Mouriki D, Dimitriou-Nikolakis P, Iliopoulos G (2012) Quantitative assessment of geotopes as an effective tool for geoheritage management. Geoheritage 4(3):177-193

Fuertes-Gutiérrez I, Fernández-Martínez E (2010) Geosites inventory in the Leon Province (Northwestern Spain): a tool to introduce geoheritage into regional environmental management. Geoheritage 2(1-2):57-75

Fuertes-Gutiérrez I, Fernández-Martínez E (2012) Mapping geosites for geoheritage management: a methodological proposal for the Regional Park of Picos de Europa (León, Spain). Environ Manag 50:789-806

Garcia-Cortés A, Rábano I, Locutura J, Bellido F, Fernández-Gianotti J, Martín-Serrano A, Quesada C, Barnolas A, Durán JJ (2001) First Spanish contribution to the Geosites Project list of the geological frameworks established by consensus. Episodes 24(2):79-92

García-Cortés A, Carcavilla Urquí L (2009) Documento metodológico para la elaboración del inventario español de lugares de interés geológico (IELIG), version 12. Instituto Geológico y Minero de, España, Madrid

Grandgirard V (1999) Switzerland - the inventory of geotopes of national significance. In: Barettino D, Vallejo M, Gallego E (eds) Towards the balanced management and conservation of the geological heritage in the new millenium. Spain, Sociedad Geológica de España, Madrid, pp 234-236

Gray JM (2008) Geodiversity: developing the paradigma. Proc Geol Assoc 119:287-298

Gray JM (2013) Geodiversity: valuing and conserving abiotic nature, 2nd edn. John Wiley \& Sons, Chichester

Henriques MH, Pena dos Reis R, Brilha J, Mota TS (2011) Geoconservation as an emerging geoscience. Geoheritage 3(2):117-128

Hjort J, Luoto M (2012) Can geodiversity be predicted from space? Geomorphology 153-154:74-80

JNCC (Joint Nature Conservation Committee) (1977) Guidelines for selection of Earth Science SSSIs. URL: http://jncc.defra.gov.uk/ page-2317. Accessed in January 2014

Lapo AV, Davydov VI, Pashkevich NG, Petrov VV, Vdovets MS (1993) Methodic principles of study of geological monuments of nature in Russia. Stratigraphy and Geological Correlations $\mathrm{I}(6): 636-644$

Lima FF, Brilha JB, Salamuni E (2010) Inventorying geological heritage in large territories: a methodological proposal applied to Brazil. Geoheritage 2(3-4):91-99

McKeever P, Zouros N, Patzak M, Weber J (2010) The UNESCO global network of national geoparks. In: Newsome D, Dowling R (eds) Geotourism: the tourism of geology and landscape. Goodfellow Publishers Ltd, Oxford, pp 221-230

Parkes MA, Morris JH (1999) The Irish Geological Heritage Programme. In: Barettino D, Vallejo M, Gallego E (eds) Towards the balanced management and conservation of the geological heritage in the new millenium. Spain, Sociedad Geológica de España, Madrid, pp 60 64
Patzak M, Eder E (1998) "UNESCO GEOPARK". A new programme- a new UNESCO label. Geol Balc 28(3-4):33-35

Pellitero R, González-Amuchastegui MJ, Ruiz-Flaño P, Serrano E (2011) Geodiversity and geomorphosite assessment applied to a natural protected area: the Ebro and Rudron gorges Natural Park (Spain). Geoheritage 3:163-174

Pellitero R, Manosso F, Serrano E (2014) Mid- and large-scale geodiversity calculation in Fuentes Carrionas (NW Spain) and Serra do Cadeado (Paraná, Brazil): methodology and application for land management. Geogr Ann Ser A Phys Geogr. doi:10.1111/ geoa. 12057

Pena dos Reis R, Henriques MH (2009) Approaching an integrated qualification and evaluation system for geological heritage. Geoheritage 1:1-10

Pereira P, Pereira DI (2010) Methodological guidelines for geomorphosite assessment. Géomorphol Relief, Processus, Environ 2:215-222

Pereira P, Pereira DI (2012) Assessment of geosites tourism value in geoparks: the example of Arouca Geopark (Portugal). Proceedings of the 11th European Geoparks Conference, Arouca: 231-232

Pereira P, Pereira DI, Alves MIC (2007) Geomorphosite assessment in Montesinho Natural Park (Portugal). Geogr Helv 62:159-168

Pereira DI, Pereira P, Brilha J, Santos L (2013) Geodiversity assessment of Paraná State (Brazil): an innovative approach. Environ Manag 52(3):541-552

Pralong JP, Reynard E (2005) A proposal for the classification of geomorphological sites depending on their tourist value. Quaternario 18(1):315-321

Prosser CD, Burek CV, Evans DH, Gordon JE, Kirkbride VB, Rennie AF, Walmsley CA (2010) Conserving geodiversity sites in a changing climate: management challenges and responses. Geoheritage 2:123-136

Reynard E (2009) The assessment of geomorphosites. In: Reynard E, Coratza P, Regolini-Bissig G (eds) Geomorphosites. Verlag Dr. Friedrich Pfeil, Munchen, pp 63-71

Reynard E, Fontana G, Kozlik L, Scapozza C (2007) A method for assessing "scientific" and "additional values" of geomorphosites. Geographica Helvetica Jg. 62. Heft 3:148-158

Reynard E, Coratza P (2013) Scientific research on geomorphosites. A review of the activities of the IAG working group on geomorphosites over the last twelve years. Geogr Fis Dinam Quat 3:1-10

Serrano E, Ruiz-Flaño P, Arroyo P (2009) Geodiversity assessment in a rural landscape: Tiermes-Caracena area (Soria, Spain). Memorie Descrittive Della Carta Geoligica d'Italia 87:173-180

Silva JP, Rodrigues C, Pereira DI (2014) Mapping and analysis of geodiversity indices in the Xingu River Basin, Amazonia, Brazil. Geoheritage. doi:10.1007/s12371-014-0134-8

White S, Mitchell M (2006) Geological heritage sites: a procedure and protocol for documentation and assessment. AESC2006, Melbourne, Australia, pp 2

Wimbledon WA (2011) Geosites - a mechanism for protection, integrating national and international valuation of heritage sites. Geologia dell'Ambiente, supplemento n. 2/2011:13-25

Wimbledon WA, Smith-Meyer S (eds) (2012) Geoheritage in Europe and its conservation. ProGEO, Oslo

Wimbledon WA, Benton MJ, Bevins RE, Black GP, Bridgland DR, Cleal CJ, Cooper RG, May VJ (1995) The development of a methodology for the selection of British Geological sites for geoconservation: part 1. Mod Geol 20:159-202

Zouros N (2004) The European Geoparks Network. Geological heritage protection and local development. Episodes 27(3):165171 